\title{
Oleochemicals I: Studies on the preparation and the structure of lithium soaps
}

\author{
By Zein E. Shoeb, Sayed M. Hammad and A.A. Yousef \\ National Research Centre, Dokki, Cairo. Egypt.
}

\section{RESUMEN}

Oleoquímica I: Estudios sobre la preparación y la estructura de los jabones de litio.

Se han preparado estearato, palmitato, miristato, laurato, caprato y caprilato de litio por fusión. Se ha realizado el análisis elemental, los espectros de absorción en el infrarrojo y las difracciones de rayos $X$ de los jabones de litio preparados, además del análisis termogravimétrico de los mismos.

Las sales de litio anhidra de los ácidos con 12 átomos de carbono o menos mostraron una estabilidad térmica hasta los $300 \pm 78^{\circ} \mathrm{C}$ dependiendo de la longitud de la cadena. Por otro lado las sales con 14 átomos de carbono o más se descompusieron a $126+4{ }^{\circ} \mathrm{C}$ formándose carbonato de litio.

Los jabones homólogos de litio mostraron una estructura cristalina similar, siendo los enlaces metal-oxígeno del mismo tipo para los ácidos grasos de número de átomos de carbono entre 8 y 18.

Sin embargo el ángulo de inclinación que forma la molécula con el plano basal aumentó con la disminución del número de átomos de carbono, lo que se observó por difracción de rayos $\mathrm{X}$.

Se comprobó por espectroscopía infrarroja la intensificación del carácter iónico del enlace metal-oxígeno al disminuir el número de átomos de carbono.

PALABRAS-CLAVE: Análisis elemental - Análisis termogravimétrico - Difracción de rayos $X$ - Espectrofotometría infrarroja Hidróxido de litio - Jabón metálico.

\section{SUMMARY}

Oleochemicals I: Studies on the preparation and the structure of lithium soaps.

Lithium stearate, palmitate, myristate, laurate, caprate and caprylate were prepared by means of fusion method. Elementary analysis and the infrared absorptions spectra of the prepared lithium soaps as well as their $\mathrm{X}$-ray diffractions and the thermogravimetric analyses were carried out.

The anhydrous lithium salts of fatty acids with 12 carbon atoms or less showed thermal stability up to ca. $300 \pm 78{ }^{\circ} \mathrm{C}$ depending on the chain length. On other hand the salts with 14 carbon atoms or more were decomposed at $126 \pm 4{ }^{\circ} \mathrm{C}$ leading to formation of lithium carbonate.

The homologous lithium soaps had very similar crystal structure among them and their metal -to- oxygen bonds were similar for the acyl chains between 8 and 18 carbons. However the angle of inclination of the molecular axes to the basal plane increased with the decreasing of the number of carbon atoms of the fatty acid chain, as determined by X-ray diffraction. In addition, the ionic character of the metal -to- oxygen bond was enhanced with the decrease of the number of carbon atoms as shown by infrared spectroscopy.

KEY-WORDS: Elementary analysis - Infrared spectrophotometry Lithium hydroxide - Metallic soap - Thermal gravimetric analysis $X$-ray diffraction.

\section{INTRODUCTION}

The term metallic soap is used to describe alkaline earth and heavy metal salts of fatty acids that are insoluble in water and either soluble in or solvated by organic solvents, such as aromatic hydrocarbons, chlorinated or hydrogenated hydrocarbons. They are also soluble in oils, greases and fatty acids preferably naphthenate, linoleate, myristate, palmitate, stearate, and cerotinate successively. Lithium stearate is used in lubricating grease as gelling agent because it gives a better thermal resistance property.

Ralston (1) prepared the lithium soaps of lauric, myristic, palmitic and stearic acids by adding the calculated amount of lithium acetate to ethanol solution of the respective fatty acids and determined the solubility of those soaps in a number of solvents. They found that the lithium salts of the long chain fatty acids are sparingly soluble in water and somewhat were soluble in ethanol.

The same authors reported the following melting points for the lithium soaps: laurate 229.2-229.8, myristate 223.6-224.2, palmitate 224-225, stearate $220.5-221.5^{\circ} \mathrm{C}$.

Lottmoser and Giese (2) reported the preparation of lithium salts of higher fatty acids and also measured the surface tension of their solutions. Vold (3) prepared lithium palmitate using precipitation method.

Many investigators (4-7) studied the lubricant character of plastics and greases using lithium soaps. Barbooty et al., (8) and Mysak et al., (9) studied the thermogravimetric analysis of some lithium soaps as lithium stearate, lithium 12-hydroxy stearate and related greases.

In this paper we describe the preparation of six lithium soaps with fatty acids having carbon chain of 18 (stearic acid) till carbon chain of 8 (caprylic acid). These soaps will be prepared by fusion method and subjected to Elementary analysis, IR-analysis, thermogravimetric analysis, and finally X-ray diffraction measurements.

\section{MATERIALS AND METHODS}

- Lithium hydroxid-1-hydrate, Assay $98 \%$; Riedelde Haën

- Fatty acids C18-C8 (Merck) Assay «GC» (95-99\%). 


\subsection{Preparation of Lithium Soaps}

The fatty acids used for the preparation of lithium soaps under investigation are stearic acid, palmitic acid, myristic acid, lauric acid, capric acid and caprylic acid. The lithium soaps of the above fatty acids are prepared by fusion method using lithium hydroxide-1-hydrate.

\section{Procedure:}

- Equimolecular amounts of the lithium hydroxide1-hydrate and the corresponding fatty acid are melted together at elevated temperature. The required reaction temperature of each of the six lithium soaps is specific.

- The calculated weight of the fatty acid is weighed in $250 \mathrm{ml}$ glass beaker which heated in an oil bath at the required temperature.

- The corresponding calculated weight of the lithium hydroxide-1-hydrate is added gradually and slowly to the melted fatty acid during a period of 20 minutes with constant stirring.

- The reaction mixture is agitated (1000 r.p.m.) for another 20 minutes to complete the dehydration reaction period during which considerable foaming occures.

- The resulting hot lithium soap is transfered into a petri dish and cooled. On cooling the soap solidifies to the required particle size.

\section{RESULTS AND DISCUSSION}

\subsection{Elementary Analysis}

The check of purity of the lithium soaps were made by the elementary analysis as show in Table I.

Table I

Elementary Analysis of Lithium Soaps

\begin{tabular}{|c|c|c|c|c|}
\hline Soap & & $\% \mathrm{Li}$ & $\% \mathrm{C}$ & $\% H$ \\
\hline Lithium stearate & $\begin{array}{l}\text { Found: } \\
\text { Calculated: }\end{array}$ & $\overline{2.4}$ & $\begin{array}{c}74 \\
74.3\end{array}$ & $\begin{array}{l}12.5 \\
12.1\end{array}$ \\
\hline Lithium palmitate & $\begin{array}{l}\text { Found: } \\
\text { Calculated: }\end{array}$ & $\overline{2.6}$ & $\begin{array}{c}73.3 \\
73\end{array}$ & $\begin{array}{l}13.7 \\
13.3\end{array}$ \\
\hline Lithium myristate & $\begin{array}{l}\text { Found: } \\
\text { Calculated: }\end{array}$ & $\overline{3}$ & $\begin{array}{c}70.6 \\
71\end{array}$ & $\begin{array}{l}11.2 \\
11.5\end{array}$ \\
\hline Lithium laurate & $\begin{array}{l}\text { Found: } \\
\text { Calculated: }\end{array}$ & $\overline{3.4}$ & $\begin{array}{l}69.8 \\
69.8\end{array}$ & $\begin{array}{l}11.3 \\
11.2\end{array}$ \\
\hline Lithium caprate & $\begin{array}{l}\text { Found: } \\
\text { Calculated: }\end{array}$ & $\overline{3.9}$ & $\begin{array}{l}66.7 \\
67.3\end{array}$ & $\begin{array}{l}10.2 \\
10.7\end{array}$ \\
\hline Lithium caprylate & $\begin{array}{l}\text { Found: } \\
\text { Calculated: }\end{array}$ & $\overline{4.6}$ & $\begin{array}{l}63.4 \\
63.9\end{array}$ & $\begin{array}{c}10.2 \\
10\end{array}$ \\
\hline
\end{tabular}

\subsection{Infrared Absorption Spectra of Lithium Soaps}

Infrared absorption spectra of the lithium soaps under investigation, and their corresponding fatty acids, namely, stearic, palmitic, myristic, lauric, capric and caprylic acid were determined with a pu 9712 infrared spectrophotometric recording by the potassium bromide pellet technique in the sodium chloride region $\left(4000-200 \mathrm{~cm}^{-1}\right)$ at room temperature (ca. $25^{\circ} \mathrm{C}$ ).

Figure 1 showes the infrared absorption spectra of the stearic and the lithium stearate. The frequencies $\left(\mathrm{cm}^{-1}\right)$ of the absorption maxima in the both spectra are also given with assignments for the most of them in Table II.

There are marked differences between the spectrum of the stearic acid and that of the lithium stearate in some spectral region (Figure 1). The absorption maxima which are characteristic of the aliphatic portion of the acid molecule are essentially unchanged on going from the acid to the soap. They are assigned with ease by referring to a table of characteristic group frequencies. It is well known that the fatty acids in the solid state exist with the dimeric structure through hydrogen bonding. The absorption maxima in the spectrum of the stearic acid at 3200-2600 (very broad, probably consisting of two separate broad absorption), 1702, 1431, 1296 and $943 \mathrm{~cm}^{-1}$ are thus associated with the localized $-\mathrm{COOH}$ group of the acid molecule in the dimeric structure. In the spectrum of lithium stearate the strong absorption maximum at $1702 \mathrm{~cm}^{-1}$ which has its orgin in the $C=O$ of the acid molecule has disappeared completely. This disappearance of the carbonyl frequancy in the soap spectrum indicates the fact that there is a complete resonance in the two C - O bonds of the carboxyl group of the soap molecule.

Duval et al., (10) have shown from the extensive investigations of the infrared absorption spectra of many metal salts of mono- or dibasic organic acid, whether acyclic or aromatic that the $\omega_{1}$ frequencies lie in the region $1400-1300 \mathrm{~cm}^{-1}$, the $\omega_{2}$ frequencies in the region $1610-1550 \mathrm{~cm}^{-1}$ and the $\omega_{3}$ frequencies in the region $950-800 \mathrm{~cm}^{-1}$.

Similar assignments were made for all the lithium soaps: Again, the absorptions due to the aliphatic portion of the soap molecule are in general similar in intensities and in their frequencies of absorption maxima, although slight but significant spectral differences can be observed in some restricted regions.

Of course, there exist considerable differences in the absorptions due to the aliphatic portion of soap molecules if the spectra of soaps of different fatty acids are compared. 


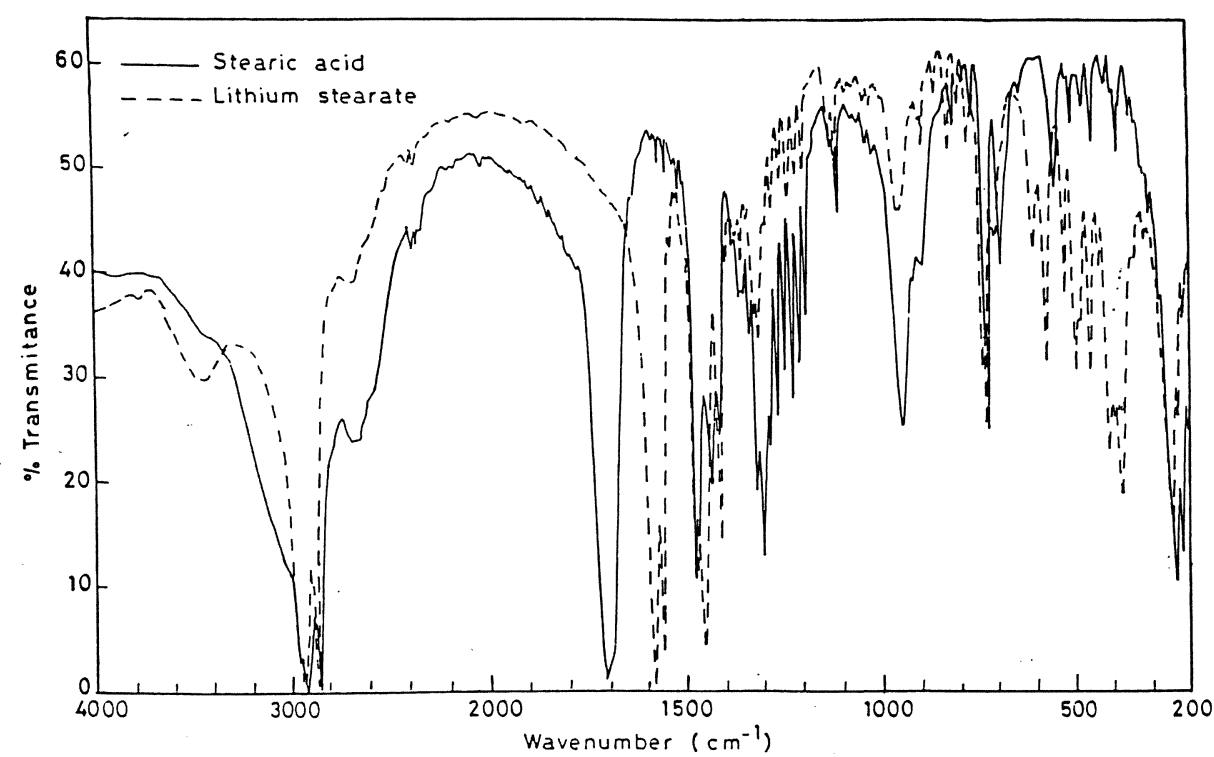

Figure 1

IR Absorption Spectra of Stearic acid and Lithium Stearate

Table II

The Frequencies $\left(\mathrm{cm}^{-1}\right)$ of Absorption Maxima in the Spectra of Lithium Soaps (Fatty Acids from $\mathrm{C}_{8}$ to $\mathrm{C}_{18}$ ) in the region $4000-700 \mathrm{~cm}^{-1}$.

\begin{tabular}{|c|c|c|c|c|c|c|}
\hline \multicolumn{6}{|c|}{ Frequency $\left(\mathrm{cm}^{-1}\right)$} & \multirow{2}{*}{ Assignement } \\
\hline Li caprylate & Li caprate & Li laurate & Li myristate & Li palmitate & Li stearate & \\
\hline 3446 (b) & 3446 (b) & 3446 (b) & 3446 (b) & 3446 (b) & 3446 (b) & Broad absorption of $\mathrm{O}-\mathrm{H}$ stretching vibration \\
\hline 2960 (sh) & 2960 (sh) & 2960 (sh) & 2960 (sh) & 2960 (sh) & 2960 (sh) & $\mathrm{CH}_{3}, \mathrm{C}-\mathrm{H}$ antisym . stretch \\
\hline $2922(s)$ & 2920 (s) & 2918 (s) & 2918 (vs) & 2918 (vs) & 2914 (vs) & $\mathrm{CH}_{2}, \mathrm{C}-\mathrm{H}$ antisym . stretch \\
\hline $2850(s)$ & $2850(s)$ & $2848(s)$ & 2848 (vs) & 2848 (vs) & 2848 (vs) & $\mathrm{CH}_{2}, \mathrm{C}-\mathrm{H}$ sym . stretch \\
\hline 1579 (vs) & 1579 (s) & 1599 (vs) & 1580 (vs) & 1580 (vs) & 1580 (vs) & $\mathrm{COO}^{\circ}, \mathrm{C}-\mathrm{O}$ antisym stretch vibration $\left(\omega_{2}\right)$ \\
\hline 1556 (vs) & $1556(s)$ & $1556(s)$ & 1556 (vs) & $1556(s)$ & $1556(s)$ & \\
\hline \multirow[t]{2}{*}{1446 (vs) } & $1446(s)$ & $1446(s)$ & $1446(s)$ & $1450(s)$ & $1448(s)$ & $\mathrm{CH}_{2}$ deform \\
\hline & $1402(\mathrm{~s})$ & $1402(s)$ & 1402 (s) & $1402(s)$ & $1403(s)$ & COO', C-O sym stretch vibration $\left(\omega_{1}\right)$ \\
\hline $1342(\mathrm{~m})$ & $1340(w)$ & $1340(\mathrm{~m})$ & $1340(\mathrm{~m})$ & $1354(\mathrm{~m})$ & $1350(s)$ & $\mathrm{CH}_{2}$ (adjacent to $\mathrm{COO}^{-}$group deform) \\
\hline $1380(\mathrm{~m})$ & $1380(\mathrm{~m})$ & $1380(\mathrm{~m})$ & $1380(\mathrm{~m})$ & $1380(\mathrm{~m})$ & $1375(\mathrm{~m})$ & $\mathrm{CH}_{3}$ sym deform \\
\hline \multirow[t]{2}{*}{$1309(\mathrm{~m})$} & $1315(w)$ & $1319(\mathrm{~m})$ & $1320(\mathrm{~m})$ & $1323(\mathrm{~m})$ & $1322(\mathrm{~m})$ & \\
\hline & & & $1302(\mathrm{~m})$ & $1306(\mathrm{~m})$ & $1298(m)$ & - $\mathrm{CH}_{2}$ twist and wag \\
\hline \multirow[t]{2}{*}{$1213(w)$} & & $1255(w)$ & $1242(w)$ & $1232(w)$ & $1261(w)$ & (Progressive bands) \\
\hline & & $1196(w)$ & $1190(w)$ & $1180(w)$ & $1240(w)$ & \\
\hline \multirow[t]{4}{*}{$1113(w)$} & $1118(w)$ & $1118(w)$ & $1119(w)$ & $1118(w)$ & $1223(w)$ & $\mathrm{CH}_{3}$ rocking \\
\hline & & & & & $1203(w)$ & \\
\hline & & $1088(w)$ & $1093(w)$ & $1099(w)$ & $1186(w)$ & \\
\hline & & $982(w)$ & & $1010(v w)$ & $1105(w)$ & \\
\hline \multirow[t]{2}{*}{$919(w)$} & $928(v w)$ & $929(w)$ & $930(w)$ & $933(w)$ & $950(w)$ & $\mathrm{COO}^{-}$deform $\left(\omega_{3}\right)$ \\
\hline & & & $906(w)$ & $891(n w)$ & & \\
\hline \multirow[t]{2}{*}{$866(m)$} & & & $852(w)$ & $851(w)$ & & \\
\hline & $829(v w)$ & $823(w)$ & $820(w)$ & $816(\mathrm{vw})$ & $814(w)$ & \\
\hline \multirow[t]{2}{*}{$775(w)$} & & $785(w)$ & $785(w)$ & $787(w)$ & $764(\mathrm{vw})$ & \\
\hline & & & $756(w)$ & $728(\mathrm{~s})$ & $730(s)$ & \\
\hline \multirow[t]{2}{*}{$723(m)$} & $719(w)$ & $719(\mathrm{~s})$ & 719 (s) & $719(\mathrm{~s})$ & $719(\mathrm{~s})$ & - $\mathrm{CH}_{2}$ rocking \\
\hline & & & & $702(\mathrm{~m})$ & & \\
\hline
\end{tabular}


The $\omega_{1}, \omega_{2}$ frequencies vary widely in a complicated manner from soap to another soap. The $\omega_{1}$ frequencies fall into the region of the $\mathrm{C}-\mathrm{H}$ deformation modes, so that in some cases an exact determination of the frequency of the absorption maximum could not be achieved or only an approximate value be given to it. The $\omega_{2}$ absorptions for some soaps split into two large absorptions or have one or more shoulders. But at present stage, the authors Cany conclusive explanation for such a result. It may be attributed to different types of crystalline field acting. The obtained spectra in the region $4000-200 \mathrm{~cm}^{-1}$ of the lithium soaps are reproduced in Figure 2 and the $\omega_{1}, \omega_{2}, \omega_{3}$ frequencies of them are tabulated in Table III. The following parts of the soap spectra are of special interest and will be discussed one by one:

Table III

The assigned $\omega_{1}, \omega_{2}$, and $\omega_{3}$ Frequencies of the Lithium Soaps

\begin{tabular}{cccc}
\hline \multirow{2}{*}{ Soap } & \multicolumn{3}{c}{${\text { Frequency } \mathrm{cm}^{-1}}$} \\
\cline { 2 - 4 } & $\omega_{1}$ & $\omega_{2}$ & $\omega_{3}$ \\
\hline Li caprylate & 1446 & 1579 & 919 \\
& & 1556 & \\
Li caprate & 1446 & 1579 & 928 \\
& 1402 & 1556 & \\
Li laurate & 1446 & 1579 & 929 \\
& 1402 & 1556 & \\
Li myristate & 1446 & 1580 & 930 \\
& 1402 & 1556 & \\
Li palmitate & 1450 & 1580 & 933 \\
& 1402 & 1556 & \\
Li stearate & 1448 & 1580 & 950 \\
& 1403 & 1556 & \\
\hline
\end{tabular}

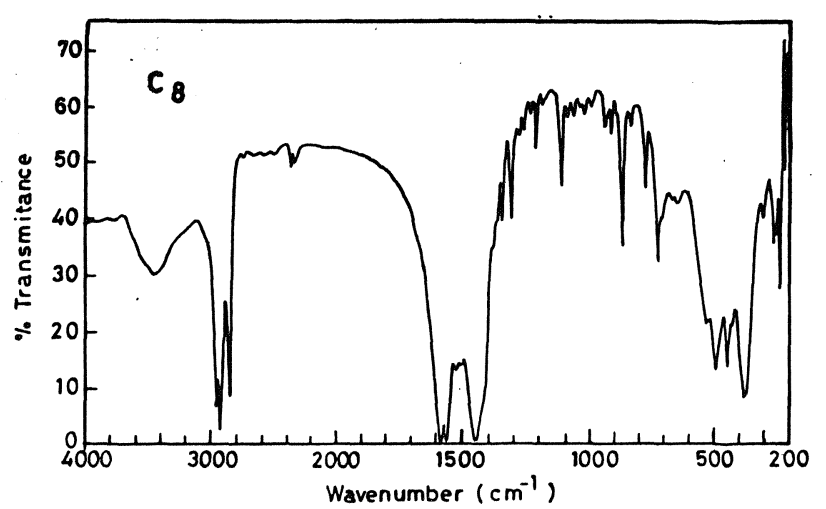

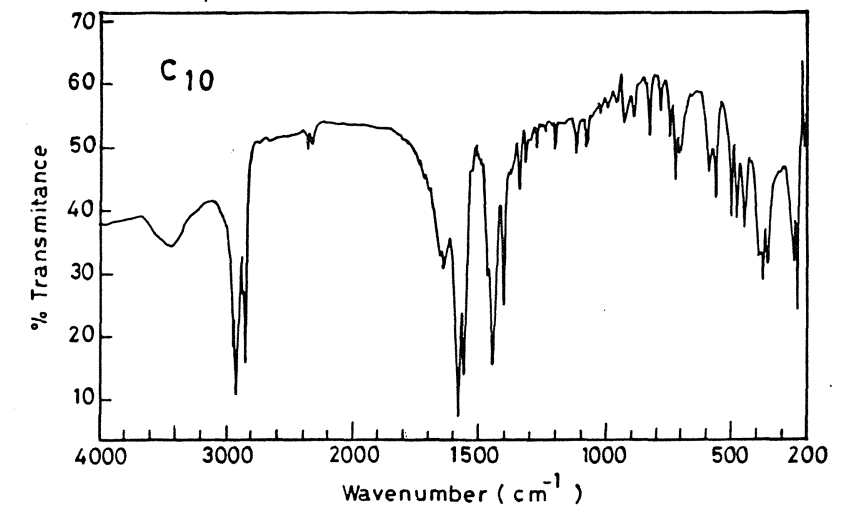

Figure 2a

IR Absorption Spectra of Lithium Soaps $\left(C_{8} \& C_{10}\right)$
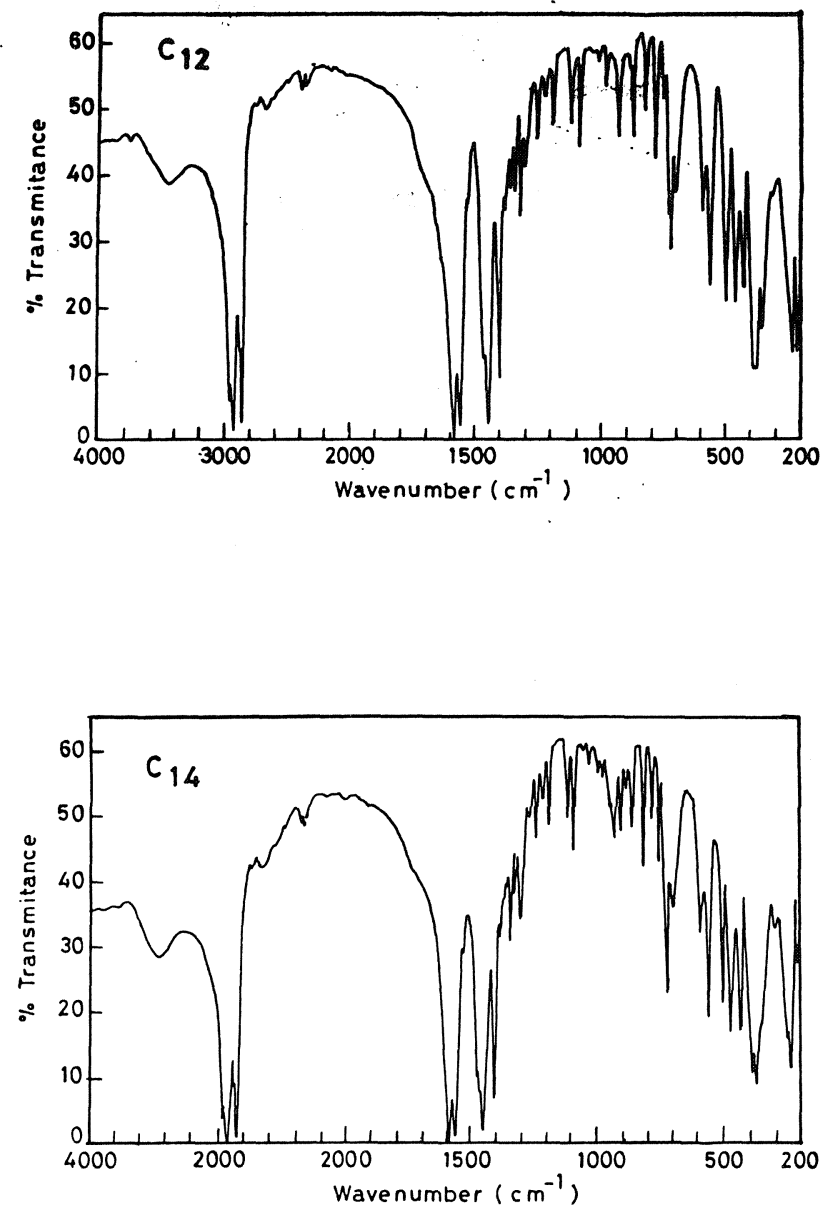

Figure $2 b$

IR Absorption Spectra of Lithium Soaps $\left(C_{12} \& C_{14}\right)$ 


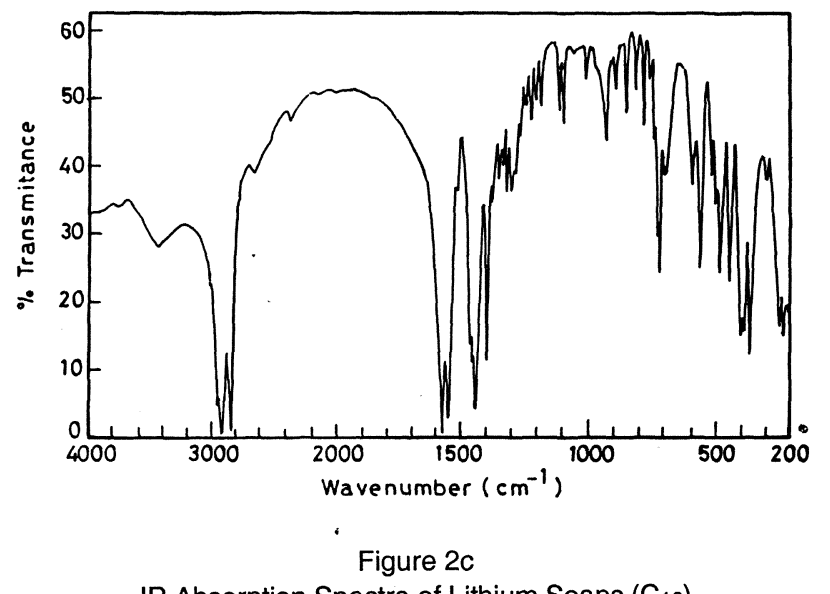

IR Absorption Spectra of Lithium Soaps $\left(\mathrm{C}_{16}\right)$

\section{$A-4000-2800 \mathrm{~cm}^{-1}$}

Absorption here are associated with the $\mathrm{O}-\mathrm{H}$ stretching vibration of hydrated water. All the six lithium soaps give no absorptions in the spectral region higher than $3610 \mathrm{~cm}^{-1}$. This is interpreted as indicating that the $\mathrm{O}-\mathrm{H}$ stretching vibrations in these hydrated soaps are not completely free, probably because of hydrogen bonding. As shown in Figure 2 $(a \& b)$ they show very broad absorption with one peak at $3446 \mathrm{~cm}^{-1}$, undoubtedly composed of many absorptions and this gives an evidence that there exist different types of hydrogen bonding, because of presence of many oxygen atoms in the polar head of soap molecules in a crystal lattice. In the region $3000-2800 \mathrm{~cm}^{-1}$ three absorption spectra peaks, mainly, at 2960,2918 and $2848 \mathrm{~cm}^{-1}$ representing the aliphatic chain appeared in all the six lithium soaps.

\section{$B-1800-1350 \mathrm{~cm}^{-1}$}

In the spectra of all the six lithium soaps, the resonance structure of ionized carboxyl is preserved in the soap crystal, and the metal -to- oxygen bond in it has an ionic character.

In this part of the soap spectra, strong absorption maxima associated with the $\omega_{1}$ and the $\omega_{2}$ mode of the ionized carboxyl vibration are observed in all the six lithium soaps as shown in Table III. The assigned $\omega_{1}$ and $\omega_{2}$ frequencies are more or less the same of all lithium soaps under investigation. Also around $1450 \mathrm{~cm}^{-1}$ there is specific peaks for methylene deformation. The terminal methyl groups are represented at $1380 \mathrm{~cm}^{-1}$ in all the lithium soaps.

\section{$C-1350-1180 \mathrm{~cm}^{-1}$ and near $720 \mathrm{~cm}^{-1}$}

In the vicinity of $720 \mathrm{~cm}^{-1}$ of soap spectra, absorptions with strong intensity are observed as a singlet with maxima at $719 \mathrm{~cm}^{-1}$ in case of $\mathrm{Li}$ caprylate and $\mathrm{Li}$ caprate and as a doublet with maxima at 719 and $723 \mathrm{~cm}^{-1}$ in case of Li laurate, myristate, palmitate and stearate. These absorptions are associated with a rocking vibration of a chain of successive methylene group - $\left(\mathrm{CH}_{2}\right)_{n}-$ and are sensitive to a manner of hydrocarbon chain packing.

In the region $950-916 \mathrm{~cm}^{-1}$ of the soap spectra, absorption maxima associated with the $\omega_{3}$ mode of the ionized carboxyl vibration are also observed.

In the region $1350-1180^{\circ} \mathrm{cm}^{-1}$, many absorptions approximately equally spaced are seen, with a medium or a weak intensity. These absorptions are assigned to wagging and twisting vibrations of chains of successive methylene groups of soap molecule (the progressive bands). Again, it seems that these absorptions are sensitive to crystallizations of soaps. As a conclusion, it seems that the homologous soaps of the lithium metal have a very similar crystal structure to one another and have the metal-to-oxygen bonds having the almost same character, over the range of the number of carbon atoms $8-18$ of the fatty acid radical. Also the enhanced ionic character of the metal-to-oxygen bond with decreasing the number of carbon atoms is implied by infrared spectra of them.

\subsection{Thermal Gravimetric Analysis of the Lithium Soaps}

The lithium soaps are subjected to thermal analysis using Perkin-Elmer, 7 series thermal analysis system with a differential scanning calorimeter cell. The rate of heating was $10^{\circ} \mathrm{C} / \mathrm{min}$ in a stream of air with a flow rate of $30 \mathrm{~cm}^{3} / \mathrm{min}$.

Figure 3 (as a representative example) presents Thermal Gravimetry (TG) and Derivative Thermal Gravimetry (DTG) plots of lithium laurate. The courses of TG and DTG curves suggest that the salt starts its dehydration at the temperature range between 50 and $130{ }^{\circ} \mathrm{C}$. The dehydrated salt starts its decomposition processes by the first step which starts from 212 and ends at $404^{\circ} \mathrm{C}$. This step may be attributed to the cracking of the organic chain (tail) of soap leading to volatilization of eight methylene group in the form of volatile gases (after combustion with the air) leaving lithium butyrate according to the following equation.

$\mathrm{CH}_{3}\left(\mathrm{CH}_{2}\right)_{10} \mathrm{COOLi} 212-404^{\circ} \mathrm{CCH}_{3}\left(\mathrm{CH}_{2}\right)_{2} \mathrm{COOLi}+8 \mathrm{CO}_{2}+8 \mathrm{H}_{2} \mathrm{O}$

The resulted butyrate shows unstability at such temperature, decomposed between 404 and $483^{\circ} \mathrm{C}$ and transformed to lithium bicarbonate according to the equation [2].

$\mathrm{CH}_{3}\left(\mathrm{CH}_{2}\right)_{2} \mathrm{COOLi} 404-483^{\circ} \mathrm{CLiHCO}_{3}+3 \mathrm{CO}_{2}+3 \mathrm{H}_{2} \mathrm{O}$ 
The produced bicarbonate suffers of unstability and transformed to lithium carbonate between 448 and $5500^{\circ} \mathrm{C}$. The last salt shows reasonable stability at temperatures even higher than $900^{\circ} \mathrm{C}$. A sample of the resulted carbonate was obtained in a separate experiment by heating the soap of lithium laurate at $650{ }^{\circ} \mathrm{C}$ for 6 hours. The results of chemical analysis and X-Ray diffraction patterns of the product indicates that it is composed of lithium carbonate which confirms as previous suggestion.

As can be seen from Table IV and Figure 3 the anhydrous salts of lithium soaps of long chain fatty acids which possess a number of carbon atoms higher than 12 suffer from constancy at relatively lower temperatures compared with that of short ones. The salts of myristic, palmitic and stearic show two decomposition steps before transformation to lithium carbonate. The percentages of losses during the first step amounts to 11.5, 21.0 and 28.0, respectively, and which correspond to evolution of $\mathrm{CH}_{2},\left(\mathrm{CH}_{2}\right)_{3}$ and $\left(\mathrm{CH}_{2}\right)_{5}$, in the form of volatile gases, from myristate, palmitate and stearate respectively. The second decomposition steps lead to formation of lithium bicarbonate which transformed to the corresponding carbonate as mentioned previously. It seems according to the experimental findings that the heat of combustion which accompanied the first decomposition step of lithium caprate and second decomposition step of lithium stearate is high enough to the extent which produce lithium carbonate directly without formation of the corresponding bicarbonate.

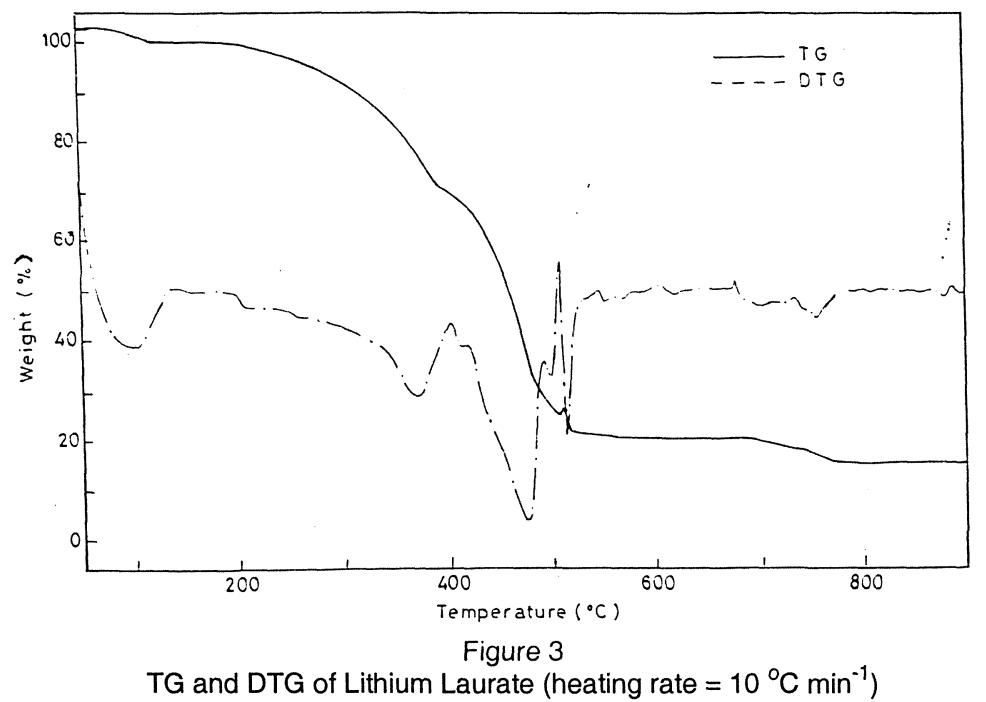

Table IV

Characterization of TG and DTG Curves for Lithium Soaps

\begin{tabular}{|c|c|c|c|c|c|}
\hline \multirow{2}{*}{ Fatty Acid } & \multirow{2}{*}{ Thermal Step } & \multirow{2}{*}{ Temp. Range } & \multicolumn{2}{|c|}{ Loss (\%) } & \multirow{2}{*}{ Thermal Product } \\
\hline & & & Actual & Calculated & \\
\hline \multirow[t]{4}{*}{ Caprylic } & dehydration & $50-112.5$ & 2 & - & $\mathrm{CH}_{3}\left(\mathrm{CH}_{2}\right)_{6} \mathrm{COOLi}$ \\
\hline & stability & $112.5-315.5$ & - & - & $\mathrm{CH}_{3}\left(\mathrm{CH}_{2}\right)_{6} \mathrm{COOLi}$ \\
\hline & decomposition & $315.5-477.5$ & 57.5 & 55 & $\mathrm{LiHCO}_{3}$ \\
\hline & decomposition & $>477.5$ & - & - & $0.5 \mathrm{Li}_{2} \mathrm{CO}_{3}$ \\
\hline \multirow[t]{3}{*}{ Capric } & dehydration & $50-120$ & 4 & - & $\mathrm{CH}_{3}\left(\mathrm{CH}_{2}\right)_{8} \mathrm{COOLi} .0 .4 \mathrm{H}_{2} \mathrm{O}$ \\
\hline & stability & $120-354$ & - & - & $\mathrm{CH}_{3}\left(\mathrm{CH}_{2}\right)_{8} \mathrm{COOLi} .0 .4 \mathrm{H}_{2} \mathrm{O}$ \\
\hline & decomposition & $354-550$ & 23 & 21 & $\mathrm{Li}_{2} \mathrm{CO}_{3}$ \\
\hline \multirow[t]{4}{*}{ Lauric } & dehydration & $50-130$ & 3 & - & $\mathrm{CH}_{3}\left(\mathrm{CH}_{2}\right)_{10} \mathrm{COOLi} .0 .34 \mathrm{H}_{2} \mathrm{O}$ \\
\hline & stability & $130-212$ & - & - & $\mathrm{CH}_{3}\left(\mathrm{CH}_{2}\right)_{10} \mathrm{COOLi} .0 .34 \mathrm{H}_{2} \mathrm{O}$ \\
\hline & decomposition & $212-404$ & 56.4 & 54.4 & $\mathrm{CH}_{3}\left(\mathrm{CH}_{2}\right)_{2} \mathrm{COOLi}$ \\
\hline & decomposition & $\begin{array}{l}404-550 \\
550-790 \\
\end{array}$ & $\begin{array}{l}68 \\
17 \\
\end{array}$ & $\begin{array}{l}67 \\
18 \\
\end{array}$ & $\begin{array}{l}\mathrm{Li} \mathrm{HCO} \\
0.5 \mathrm{Li}_{2} \mathrm{CO}_{3}\end{array}$ \\
\hline \multirow[t]{3}{*}{ Myristic } & dehydration & $52.5-123$ & 4 & - & $\mathrm{CH}_{3}\left(\mathrm{CH}_{2}\right)_{12} \mathrm{COOLi} .0 .65 \mathrm{H}_{2} \mathrm{O}$ \\
\hline & decomposition & $123-308$ & 11.5 & 12 & $\mathrm{CH}_{3}\left(\mathrm{CH}_{2}\right)_{10}-\mathrm{COOLi}$ \\
\hline & decomposition & $\begin{array}{c}308-483 \\
>475\end{array}$ & 27 & $\frac{29}{-}$ & $\begin{array}{l}\mathrm{Li} \mathrm{HCO} 3 \\
\mathrm{Li}_{2} \mathrm{CO}_{3}\end{array}$ \\
\hline
\end{tabular}


Table IV (Continued)

\begin{tabular}{|c|c|c|c|c|c|}
\hline \multirow{2}{*}{ Fatty Acid } & \multirow{2}{*}{ Thermal Step } & \multirow{2}{*}{ Temp. Range } & \multicolumn{2}{|c|}{ Loss (\%) } & \multirow{2}{*}{ Thermal Product } \\
\hline & & & Actual & Calculated & \\
\hline \multirow[t]{4}{*}{ Palmitic } & dehydration & $51-126$ & 1 & - & $\mathrm{CH}_{3}\left(\mathrm{CH}_{2}\right)_{14} \mathrm{COOLi} .0 .15 \mathrm{H}_{2} \mathrm{O}$ \\
\hline & decomposition & $126-268$ & 21 & 20 & $\mathrm{CH}_{3}\left(\mathrm{CH}_{2}\right)_{10} \mathrm{COOLi}$ \\
\hline & decomposition & $268-483$ & 25 & 26 & $\mathrm{LiHCO} 3$ \\
\hline & & $>475$ & - & - & $\mathrm{Li}_{2} \mathrm{CO}_{3}$ \\
\hline \multirow[t]{3}{*}{ Stearic } & dehydration & $52-130$ & 2 & - & $\mathrm{CH}_{3}\left(\mathrm{CH}_{2}\right){ }_{16} \mathrm{COOLi} \cdot 0.33 \mathrm{H}_{2} \mathrm{O}$ \\
\hline & decomposition & $130-350$ & 28 & 29 & $\mathrm{CH}_{3}\left(\mathrm{CH}_{2}\right){ }_{11} \mathrm{COOLi}$ \\
\hline & decomposition & $350-479$ & 12.7 & 12.7 & $0.5 \mathrm{Li}_{2} \mathrm{CO}_{3}$ \\
\hline
\end{tabular}

It can be concluded that the lithium laurate shows the highest thermal stability among the different soaps under investigation so that it is suggested to be used as a sufficient lubricant constituent in high temperature lubrication greases.

\subsection{X-ray Diffraction of Lithium Soaps}

X-ray diffraction patterns occupy an important position as one of fundamental data in the investigation of the metal soaps, especially, of the structure of greases, thickening agents, coatings and other products made from them, and of polymorphic behaviors exhibited by them.

The soaps used in this investigation are the same as studied in part II and III of this paper. X-ray diffraction patterns were determined two times for all the six lithium soaps. X-ray powder diffraction patterns were obtained at room temperature using a Siemens diffractometer (D 500) employing $\mathrm{Ni}$ - filtered $\mathrm{Cu} \mathrm{K} \alpha$ radiation $(\lambda=$ 1.5404 ?). The X-ray tube was operated at $36 \mathrm{KV}$ and 20 $\mathrm{mA}$ samples were finely ground and packed in a plastic holder. No adhesive orbinder was necessary. The diffraction angle (20) was scanned at a rate of $\mathrm{min}^{-1}$.

By using the X-ray diffractometer, automatically recorded curves of the intensity of the diffracted X-ray v.s. the diffraction angle $2 \theta$ have been obtained Bragg's interplanar spacings, $d$, were calculated from the positions of the peaks in each curve using the relation, $n \lambda=2 d \sin \theta$ where $\lambda$ is the wave length of the radiation. In Figure 4 the diffraction patterns of the six lithium soaps thus obtained are reproduced over the range of diffraction angle $2^{\circ}-60^{\circ}$. These are attributed to the diffractions of X-ray by planes of soaps in much smaller separation than the based planes.

Hence calculated spacings from these peaks are called short spacing. The distance given by the short spacings are lateral ones between one molecule and the next in a layer. Thus the short spacings may be referred to as "side» spacings (d-spacings) in another sense, to which perfect interpretation can scarcebe giuntithe lattice type and space group of the crystal are determined. However, knowledges on these side spacings still have very important values for purposes of indentification of soaps and for investigations of polymorphs exhibited by soaps.

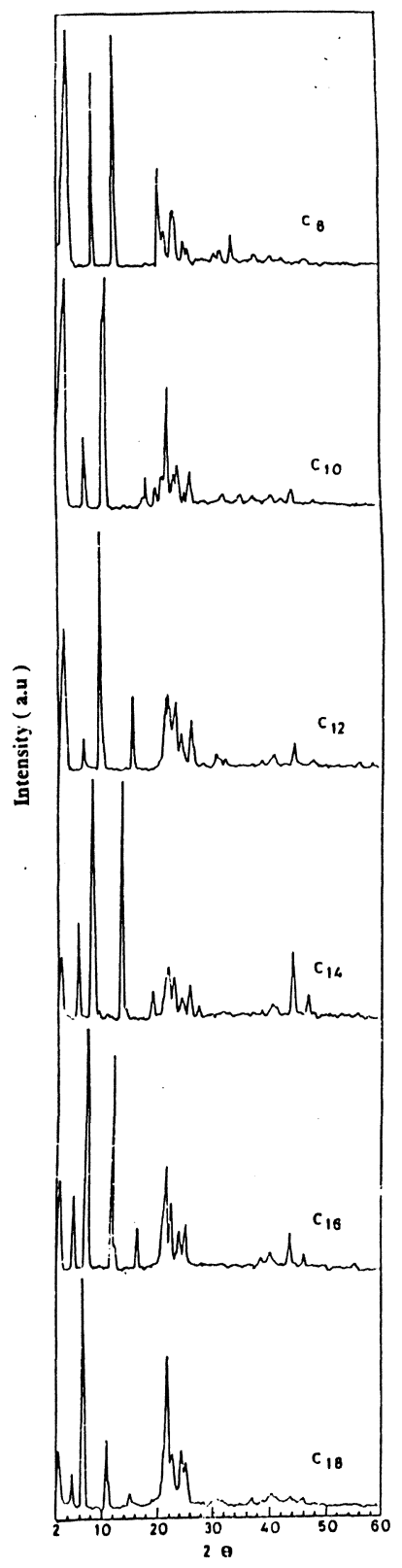

Figure 4

X-Ray diffraction Patterns of Lithium Soaps (fatty acids from $\mathrm{C}_{8}-\mathrm{C}_{18}$ ) 
Accordingly, Table $V$ represents the characteristics of short spacings of the lithium soaps under investigation.

In Figure 5 the long spacings of lithium soaps are plotted against number of carbon atoms in the fatty acid radical constituent of each soap molecule.

A good linearity for this series of lithium soaps is interpreted as indicating that zig-zag chains of the fatty acid radicals extend straight forward. The fact that the inclinations of the straight line in the mentioned figure, that is the increase in the long spacings per additional methylene group, are 2.3-2.5 $\AA$ per $\mathrm{CH}_{2}$, which is corresponding approximately to double the length of one methylene group (ca. 1.3 $\AA$ ). Is interpreted as two methylene chains (fatty acid radicals) existing between the basal planes. Thus, as a conclusion the angle of inclination of molecular axes to the basal plane seems to increase with decreasing the number of carbon atoms of the fatty acid radical, seeing from the X-ray diffraction.

Table V

Characteristics of $d \AA ̊$ Spacings of Lithium Soaps

\begin{tabular}{|c|c|c|c|c|c|c|c|c|c|c|c|c|c|c|c|c|c|}
\hline \multicolumn{3}{|c|}{ Li caprylate } & \multicolumn{3}{|c|}{ Li caprate } & \multicolumn{3}{|c|}{ Li laurate } & \multicolumn{3}{|c|}{ Li myristate } & \multicolumn{3}{|c|}{ Li palmitate } & \multicolumn{3}{|c|}{ Li stearate } \\
\hline $2 \theta$ & $\mathrm{d} \AA$ & $\mathrm{I} / \mathrm{I}^{*}$ & $2 \theta$ & $\mathrm{dA}$ & $\mathrm{I}_{0}$ & $2 \theta$ & $\mathrm{d} \AA \AA$ & $\mathrm{l} / \mathrm{l}_{0}$ & $2 \theta$ & $\mathrm{d} \AA$ & $\mathrm{l} / \mathrm{I}_{0}$ & $2 \theta$ & $\mathrm{d} \AA$ & $|/|_{0}$ & $2 \theta$ & $\mathrm{d} \AA$ & $\mathrm{I} / \mathrm{I}_{0}$ \\
\hline 4.09 & 21.6 & 100 & 3.62 & 24.4 & 100 & 3 & 29.4 & 50 & 2.58 & 34.2 & 20 & 2.38 & 37.1 & 25 & 2.11 & 41.9 & 20 \\
\hline 12.3 & 7.18 & 100 & 10.53 & 8.4 & 90 & 9.07 & 9.75 & 100 & 7.89 & 11.2 & 100 & 7.07 & 12.5 & 100 & 6.31 & 14 & 100 \\
\hline 18.4 & 4.82 & 5 & 18.14 & 4.89 & 20 & 15.2 & 5.83 & 30 & 18.2 & 4.87 & 10 & 11.83 & 7.48 & 60 & 10.47 & 8.45 & 25 \\
\hline 20.6 & 4.31 & 50 & 19.3 & 4.6 & 15 & 18.3 & 4.84 & 20 & 19.8 & 4.49 & 15 & 18.2 & 4.86 & 5 & 19.1 & 4.65 & 20 \\
\hline 21.4 & 4.15 & 10 & 20.65 & 4.3 & 20 & 20.8 & 4.27 & 30 & 20.9 & 4.25 & 30 & 21.06 & 4.22 & 30 & 20.5 & 4.33 & 20 \\
\hline 22.8 & 3.9 & 30 & 21.57 & 4.12 & 40 & 21.57 & 4.12 & 35 & 21.6 & 4.12 & 40 & 21.57 & 4.12 & 60 & 21 & 4.23 & 25 \\
\hline 23.4 & 3.8 & 30 & 22.8 & 3.9 & 10 & 22.11 & 4.02 & 30 & 22.4 & 3.97 & 30 & 22.4 & 3.97 & 40 & 20.6 & 4.11 & 70 \\
\hline 25.8 & 3.46 & 15 & 23.4 & 3.79 & 20 & 22.69 & 3.92 & 30 & 23.8 & 3.74 & 20 & 23.6 & 3.77 & 10 & 22.4 & 3.97 & 40 \\
\hline 28.1 & 3.18 & 5 & 25.65 & 3.47 & 25 & 25.45 & 3.5 & 20 & 25.3 & 3.52 & 25 & 25.16 & 3.54 & 25 & 25 & 3.56 & 20 \\
\hline 44.8 & 2.02 & 5 & 29.75 & 3 & 5 & 36.2 & 2.48 & 5 & 29.8 & 3 & 5 & 36.5 & 2.46 & 5 & 28.33 & 3.15 & 5 \\
\hline
\end{tabular}

* $\quad 1 / l_{0}$ shows the ratio of the height of the given peak to the height of the most intense peak in the given pattern.

\section{CONCLUSIONS}

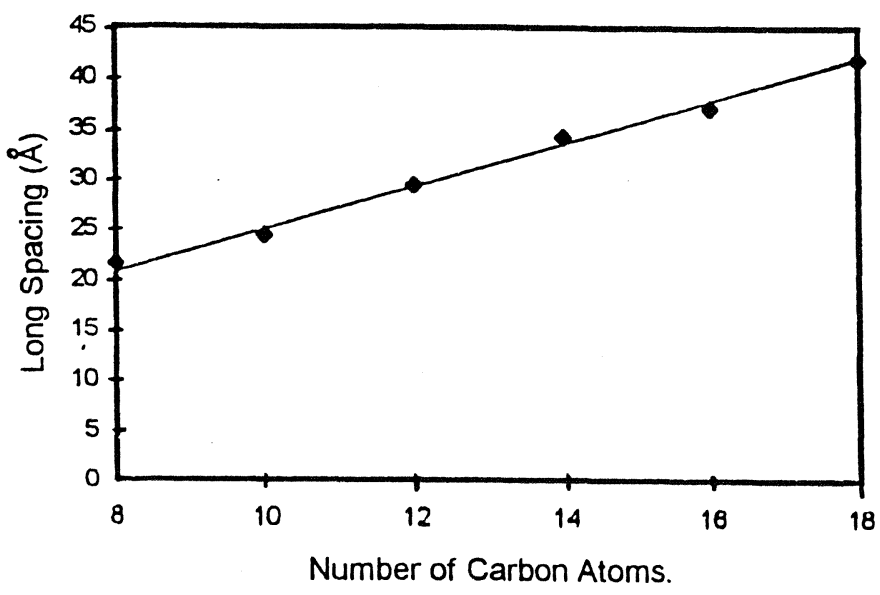

Correlation: $Y(X)=4.6162+2.0629 \times$ Variance $=0.4342$

Figure 5

The Long Spacings vs. Number of Carbon Atoms of the Fatty Acid Radical Constituent of the Lithium Soaps
1. The lithium soaps have a very similar crystal structure to one another and the metalto-oxygen bonds having the almost same character, over the range of the number of carbon atoms, 8-18 of the fatty acid radical. However the angle of inclination of molecular axes to the basal plane seems to increase with the number of carbon atoms of the fatty acid radical, seeing from the $X$-ray diffraction. And the enhanced ionic character of the metal-to-oxygen bond with decreasing the number of carbon atoms is implied by IR-spectra of them.

2. The anhydrous lithium soaps of lauric, capric, and caprylic acids show thermal stability up to ca $300 \pm 78^{\circ} \mathrm{C}$ depending on the chain length. On the other hand the lithium soaps of myristic, palmitic and stearic acids suffer from stability and decomposes at $126 \pm 4{ }^{\circ} \mathrm{C}$ leading to formation of lithium carbonate. Also lithium laurate has the highest thermal stability among the different lithium soaps so that it is suggested to be used as a sufficient lubricant constituent in high temperature lubrication grease. 


\section{REFERENCES}

1. Ralston, A. W. (1948).- «Fatty acids and their derivatives". - John Wiley \& Sons Inc., New York, 891.

2. Lottormoser, A. and Giese, E. (1935).- - "Measurement of the surface tension of solutions of potassium and lithium salts of the higher fatty acids by the ring method with exclusion of carbon dioxide and with special consideration of other disturbing effects".-Kolloid. $Z$. 73, 155.

3. Vold, M. J. (1943)._- «The phase behaviour of lithium palmitate with water and with lithium chloride and water».-J. Am. Chem. Soc. 65, 465.

4. Sosulina, L. M. and Skryabina, T. G. (1984).- «Study of the composition of the products of tribochemical transformations of plastic lubricants under rolling frication conditions".-Trenie Iznos 5 (5), 923.

5. Maeweevskii, R. M., Fuks, I. G., Ryabov, D. V., Buyanovskii, I. A. and Gar, O. E. (1984).- «Effect of polymorphic transformations on the antifriction properties of lithium lubricants". - Chem. and Techn. of Fuels and Oils 20, 137.
6. Rong-Hua, T. (1985).- - EEffects of the composition and fibrous texture of lithium soap grease on wear and friction".- Tribology International 18 (2), 121.

7. Stadler, J. F. (1986).-_ «Effect of milling lithium greases».- MLGI Spokesman (National Lubricating Grease Institute) 50 (3), 103.

8. Barbooty, M. M. and Al-Sammerrai, D. A. (1985)."Thermoanalytical investigations on lithium stearate, lithium 12- hydroxy stearate and related greases".-J. of Thermal Analysis $\mathbf{3 0}(3), 587$.

9. Mysak, A. E., Kanchenko, Yu. A., Movoded, R. D. and Kisterskaya, S. M. (1985).— «Study of retention of the liquid phase in a soap hydrocarbons system by thermogravimetric analysis».-Colloid Journal of the USSR (English) 47 (1), 147.

10. Duval, C., Lecomte, J. and Douvilla, F. (1942).Annales de Physique 17, 5. 